\title{
THE CALIFORNIA SMALL CLAIMS COURT
}

For ordinary causes, our contentious system has great merit as a means of getting the truth. But it is a denial of justice in small causes to drive litigants to employ lawyers, and it is a shame to drive them to legal aid societies to get as a charity what the state should give as a right.

Roscoe Pound ${ }^{1}$

More than half of all civil cases filed in municipal and justice courts in California are small claims cases. ${ }^{2}$ Nevertheless, little has been written concerning the nature and operation of the small claims court. ${ }^{3}$ There has been almost no empirical researcl directed at determining the types of cases filed, the nature of the plaintiffs and defendants, the amounts of the judgments rendered, the number of defaults, the average time to trial, the costs involved, and other pertinent information. It is surprising that so little is known about the workings of a judicial mechanism which accounts for a substantial number of trial cases in California's lowest courts. ${ }^{4}$ Evaluation of the utility and efficiency of the small claims court and determination of whether the original goals of the small claims movement $t^{5}$ are being achieved are impossible without current data on the functioning of the court. ${ }^{\circ}$

The small claims movenjent began in England in $1605 .^{7}$ The establishment of small claims courts was intended to provide speedy, inex-

1 Pound, The Administration of Justice in the Modern City, 26 HARv. L. REv. 302, 318 (1913).

2 The annual report of the Judicial Council of California for 1961-62 shows that 55.7\% of the 589,378 civil cases filed in municipal and justice courts were small claims cases. Small claims cases comprised a greater percentage of justice court civil cases $(76,513$ of 95,930 , or $79.7 \%$ of the cases filed) than of municipal court civil cases $(251,778$ of 493,448 , or $51 \%$ of the cases filed). Small claims represented $7.5 \%$ of the total non-parking filings (civil and criminal) of the municipal and justice courts. See Judicial CouncII of CarrFORNIA, NINETEENTH BIENAIAL Report to THE Governor AND tHe Leotstature 156-66 (1963).

3 An excellent bibliography of the pre-1940 material on the small claims courts is contained in Northrop, Small Claims Courts and Conciliation Tribunals, 3 LAW LIBRARY J. 39 (1940). For a list of more recent published material, see LouISEIL \& HAzARD, CASEs AND Materiats on Pleading and Procedure 111 (1962).

4 The dearth of material inight be attributable to a lack of general interest in the workings of such low level courts; in addition, attorneys unay be less interested in the small claims courts because they are barred fron such proceedings in California, although this fact would seein to warrant periodic scrutiny of the small claims mechanism; finally, the procedural and administrative problems of higher level courts may simply have preempted the interests of researchers in the freld of judicial administration.

5 See text accompanying notes 8-10 infra.

6 Of particular significance is the fact that the great bulk of the material available on the smail claims courts dates from the period 1913-1940; very little material has been published since 1940. See the bibliographic references cited in note 3, supra.

78 Minute Booz 11 (Special Issue, Jan. 1962). 
pensive, and informal disposition of small actions through simple proceedings conducted with an eye toward compromise and conciliation. ${ }^{8}$ The court was to be designed particularly to lielp the "poor" litigant." An informal court procedure was thought to reduce expense and delay "in cases involving small amounts and often no real issue of law."10 Further, it was believed that by securing justice to ordinary citizens in small cases, the integrity of our judicial system would be meaningfully demonstrated. ${ }^{11}$

The small claims movement led to the statutory creation of a small debt court in London in $1606 . .^{12}$ In 1846 , the new county courts were created in England to provide speedy and informal disposition of small causes. ${ }^{13}$ The first American small claims court was established in Cleveland in 1913, in response to criticism of the judicial system typified by the quoted statement of Dean Pound; the court was called the "conciliation branch" of the municipal court. ${ }^{14}$ In 1920, Massachusetts became the first state to pass a state-wide act of general application to small claims actions. ${ }^{15}$ Califorma passed a similar statute in $1921 .^{16}$

This Comment will review briefly the California procedure for small claims actions, present the methodology and results of an empirical study of the Oakland-Piedmont-Emeryville small claims court, and draw conclusions and make suggestions for reform based upon an examination of the procedural requirements and the results of the study. The discussion proceeds upon the premise that the historical goals of the small claims

8 See Sanderson v. Neimann, 17 Cal. 2d 563, 110 P.2d 1025 (1941); Smatr, Justice AND THE POOR 52-3 (1940); Scott, Small Causes and Poor Litigants, 9 A.B.A.J. 457 (1923).

- Scott, supra note 8.

10 Institute of Judicial Admomistration, Suratl Clams Courts in the United States 1 (1955). The quoted phrase may not be valid insofar as it implies that small claims usually involve uncomplicated matters of law. No correlation between jurisdictional amount and case complexity las been established. "It is superficially said that . . . larger claims . . . are more complicated. Every lawyer knows that in contract and debt actions the size of the claim has little relation to the complexity of the issues or the difficulty of the proof." Smith, op. cit. supra note 8 , at 55 . It las been stated that the average small claim is likely to be more complex than the average non-small claims case. Speech by Judge Swan of the Benicia (California) Justice Court to the Seminar in Court Administration, Boalt Hall, University of California, Berkeley, November 10, 1963. It would seem that the intention in creating small claims courts was to eliminate cases under a specified dollar amount from the dockets of the formal courts, irrespective of case complexity.

11 Smith, supra note 8 , at 252-53.

12 Comment, 34 Colum. L. REv. 932, 933 n.7 (1934).

131 HoLDSwORTH, History of ENGLISH LAw 188, 190-91 (1927). See also Smith, op. cit supra note 8 , at $42,52-53$ (1940).

14 Northrop, Small Claims Courts and Conciliation Tribunals: A Bibliography, $33 \mathrm{LAw}$ LIB. J. 39 (1940).

15 Mass. Stat. 1920, ch. 553, § 1 (now Mass. ANN. Laws ch. 218, § 21 (1953)).

16 Smith, Small Claims Procedure is Succeeding, 8 J. Am. JuD. Soc'т 247 (1924). 
movement are today's goals. Consideration of whether the original goals ought to be replaced by others is beyond the scope of this Comment.

\section{I}

\section{PROCEDURE}

The small claims court is not a separate and independent judicial tribunal existing apart from the other Cahifornia courts; it is an adjunct of all municipal and justice courts of the state and is "in the nature of a special procedure"17 eniployed to adjudicate claims small in amount. All justice court judges sit as small claims judges, and any municipal court judge may do so..$^{18}$ Generally, the court specifies particular days or times during the week for the hearing of small claims matters. ${ }^{10}$

Corporations as well as natural persons may appear as plaintiffs in California small clains actions; $;^{20}$ this is contrary to the practice of a number of states which restrict small claims plaintiffs to natural persons. ${ }^{21}$ Assignees of claims are prohibited from filing or prosecuting small claims. ${ }^{22}$ The Cahfornia courts have interpreted this prohibition broadly, refusing to restrict the proscription to assignees for collection or for purposes of suit. ${ }^{23}$ Although the purpose of forbidding suits by assignees is to prevent the use of the court as a collection agency, California places no himit upon the extent to which a particular plaintiff may use the court. ${ }^{24}$

Litigants in small claims actions may not be represented by attorneys. ${ }^{25}$ Two reasons underhe this prohibition: the parties' costs of litigation are minimized and procedure is simphified. ${ }^{26}$ In Prudential In-

178 Minute Book 4 (Special Issue, Aug. 1962).

18 Cal. Code Crv. Proc. \& 117.

19 Interview with Mr. J. R. McCloskey, Clerk of the Municipal Court, Oakdand-Piedmont-Emeryville Judicial District, October 9, 1963.

20 Prudential Ins. Co. v. Small Claims Court, 76 Cal. App. 2d 379, 173 P.2d 38 (1946).

21 See, e.g., N.Y.C. Crv. CT. ACr art. 18, § 1809 (1962), banming corporations, partnerships, or associations from the court.

22 CaI. Code Crv. Proc. § 117(f).

23 See Merchants Serv. Co. v. Small Claims Court, 35 Cal. 2d 109, 216 P.2d 846 (1950). It is permissible in California, however, to assign a right after it has been reduced to judgment. 28 Ops. CaI. Atr'y Gen. 359 (1956).

24 Although Minnesota had such a provision at one time, see Mimn. Laws 1929, ch. 242, § 3, discussed in Comment, 4 STAN. L. Rev. 237, 242 (1952), the provision is absent from the present statutes. New Hampshire formerly limited the number of claims which could be brought to not more than 5 in one week or 20 in one month; this provision was repealed in 1955. Maine repealed a numberical himitation in 1957. See INSTITUTE of Judictar ADMINistration, Smali Clams Courts in the Unted States 2, 7, 10 (Supp. 1959).

25 CaI. Code Civ. Proc. \$ 117 (g).

28 Institute of Jodictal AdMmistration, op. cit. supra note 10 , at 9. 
surance Company v. Small Claims Court, ${ }^{27}$ a due process-based objection to denial of the right to counsel in the small claims court was unsuccessful because a trial de novo with counsel may be had on appeal to the superior court. ${ }^{28}$ Although the prohibition against representation by counsel applies to corporate litigants, a corporate officer who is also an attorney is not prohibited from representing the corporation. ${ }^{20}$

Jurisdiction of the small claims court is limited to actions for the recovery of money; $;^{30}$ no action may be brought for specific performance, declaratory relief, or any other non-monetary remedy. ${ }^{31}$ The jurisdictional amount of small claims is two hundred dollars. ${ }^{32}$ Mandamus will lie as a means to compel a small claims court to entertain a proceeding over which it has jurisdiction. ${ }^{33}$ With the exception of change of venue motions, the general rules with respect to venue apply in small claims actions. ${ }^{34}$ Although change of venue motions are generally considered inapphcable, ${ }^{35}$ some judges entertain them in hardship cases. ${ }^{36}$

A prospective plaintiff initiates a small claims action by filing with the

2776 Cal. App. 2d 379, 173 P.2d 38 (1946).

28 See Cal. Code Civ. Proc. \& 117 (j).

2876 Cal. App. 2d at 386, 173 P.2d at 42.

$30 \mathrm{CAT}$. Code Crv. Proc. \& 117. Both contract and tort claims are thus allowed. Miller v. Municipal Court, 22 Cal. 2d 818, 142 P.2d 297 (1943); Leuschen v. Small Claims Court, 191 Cal. 133, 215 P. 391 (1923). CAI. Code CIv. Proc. \& 117 was amended in 1955 to provide that unlawful detainer actions may be heard in small claims courts where the amount claimed is than $\$ 200$ and the tenancy is no greater than month to month; this provision has been declared unconstitutional by the Califorma Supreme Court. Mendoza v. Small Claims Court, 49 Cal. $2 \mathrm{~d} 668,321$ P.2d 9 (1958). The court held that denial of the right to counsel at a hearing prior to dispossession constituted deprivation of property without due process of law in violation of the state constitution. The unconstitutional unlawful detainer provision has not been removed from $\$ 117$.

31 Shontz, Speedy, Informal Justice of Small Claims Court Described by Judge, 15 CAL. S.B.J. 273 (1940).

32 CAL. Code CIv. Proc. § 117. An attempt was made to raise the limit to $\$ 300$ during the 1963 legislative session. See A.B. 1191 (1963). The bill was not passed.

33 Miller v. Mumicipal Court, 22 Cal. 2d 818, 142 P.2d 297 (1943).

34 Compare Cac. Code Crv. Proc. § 117 with Cat. Code Crv. Proc. § 395.

35 While there is no statutory prohibition against changes of venue in small claims actions, and while no appellate court has held such motions inappropriate, judges generally do not allow the motions. Interview with Mr. J. R. McCloskey, Clerk of the Municipal Court, Oakland-Piedmont-Emeryville Judicial District, October 9, 1963. The rationale is that since the statutory procedure for the small claims court is "complete," motions not specifically provided for in the procedure are excluded. See note 69 infra, discussing the Spiegelman case, which employed this rcasoning to exclude a motion for a new trial in third party proceedings under CAL. Code Crv. Proc. \& 689. A.B. 1191 (1963) included a provision for change of venue in the discretion of the trial judge. The measure was not passed, possibly because it was linked with a provision raising the jurisdictional limits of the court to $\$ 300$.

${ }^{36}$ Interview with Mr. J. R. McCloskey, Clerk of the Municipal Court, Oakland-Piedmont-Emeryville Judicial District, October 9, 1963. 
clerk an unsworn declaration under penalty of perjury, ${ }^{37}$ or an affidavit, ${ }^{38}$ and paying the one dollar fee. ${ }^{39}$ The declaration or affidavit must be substantially in the form set forth in Section 117(b) of the California Code of Civil Procedure: that the defendant is indebted to the plaintiff in the sum of $X$ dollars, that demand has been made upon the defendant, and that the defendant has refused to pay. ${ }^{40}$

General practice is to allow the plaintiff to choose, at the time he files his declaration or affidavit, a trial date convement for him. The date chosen must be within the limits set by the statute. ${ }^{41}$ The plaintiff also decides at that time whether the defendant is to be served personally or by mail. ${ }^{42}$ The court has no jurisdiction to render judgment unless proof of service is filed with the court; ${ }^{43}$ however, a defendant who appears at trial where no proof of service has been filed waives this defect. ${ }^{44}$

A plaintiff unable to effect service may apply to the court for a continuance which, if granted, is in the form of an order setting a new trial date. Either party can obtain a continuance for reasons other than failure to obtain service..$^{45}$ The party requesting a continuance for other reasons must either file a written stipulation that both parties agree to a new date or appear and request a continuance at the time set for trial. ${ }^{48}$

Cahifornia, in accord with the majority of jurisdictions, does not require the defendant to answer. ${ }^{47}$ This rule is based on the desire to keep pleadings at a mimimum and the feeling that an answer is not necessary because in the majority of small claims cases there is no defense. ${ }^{48}$

The usual procedures with respect to counterclaims apply in the

37 See Cal. Code Civ. Proc. \& 2015.5.

${ }^{38}$ See CAL. Code Crv. Proc. \& 117 (a).

${ }^{39} \mathrm{~A}$ procedure is available whereby indigent plaintiffs may commence an action without paying the prescribed fees. See 8 Minute Boor 15 (Special Issue, Aug. 1962).

40 Many courts require the plaintiff to fill out a "Plaintiff's Statement" prior to filing the declaration or affidavit. This document is essentially a draft of the declaration or affidavit and is prepared in longhand by the plaintiff. It serves both as a guide to the clerk in preparing the declaration for the claimant and as documentary support in the event the claimant later charges that the declaration was incorrectly prepared. This statement is required by the Oakland-Piedmont-Enneryville Judicial District.

41 Section 117(d) limits this choice as follows: if the defendant resides within the county where the action is brought, the date of trial may be not less than 10 nor more than 30 days from the date of the order to defendant to appear; if the defendant resides outside the county, the trial date may be not less than 30 nor more than 60 days from the date of the order.

42 Cat. Code Civ. Proc. § 117 (c).

43 Cal. Code Civ. Proc. \$ 117(d).

44 Ibid.

458 Mivote Boor 18 (Special Issue, Aug. 1962).

40 Ibid.

47 Cas. Code Crv. Proc. \& 117(h).

48 Institute of JUdictal AdMonistration, op. cit. supra note 10, at 5. 
small claims court. ${ }^{49}$ If the defendant's demand is in excess of two hundred dollars, he may, as an alternative to a counterclaim, file an action in another court. ${ }^{50}$ If he does so, the small claims court must, upon defendant's fulfillment of the procedural requirements, ${ }^{51}$ order a transfer to the other court for trial of the consolidated action. ${ }^{52}$

The trial of a small claims action is short and uncomphicated..$^{53}$ There is no jury-the plaintiff is deemed to have waived his right to a jury trial by his choice of the forum ${ }^{54}$ the defendant's jury trial right is deemed satisfied by his right to a trial de novo on appeal. ${ }^{55}$ The court is not bound by technical rules of evidence; it is limited only by substantive rules of law. ${ }^{56}$ When the case is called, the plaintiff is asked by the judge to state all the facts he knows; he may thereafter present demonstrative evidence and testimony on his belialf. ${ }^{57}$ The defendant is then asked to present his side of the case. Since cross-examination need not be allowed in the small claims court, ${ }^{58}$ the judge may require questions to be channeled through the court; some judges, however, permit the parties to question witnesses and each other directly. ${ }^{59}$ The keynote througliout is simplicity. ${ }^{60}$ Many judges decide small claims cases from the bench; others take them under submission, ${ }^{61}$ notifying the litigants of the

\footnotetext{
49 Cad. Code Crv. Proc. $\$ 117(\mathrm{~h})$. However, it has been held that failure to counterclaim does not bar defendant's claim under CaI. Code Crv. Proc. \& 439 if the defendant's claim is above the jurisdictional limits of the small claims court. Sanderson v. Niemann, 17 Cal. 2d 563, 110 P.2d 1025 (1941); Thompson v. Quan, 167 Cal. App. 2d Supp. 825, 334 P.2d 1074 (1959).

50 Cal. Code Crv. Proc. $\$ 11$ (r).

61 These requirements are specified in CaI. Code Crv. Proc. $\$ 117(r)$.

62 CaI. Code Crv. Proc. \$ 117 (r).

63 See Institute of JUdiciat Adainistration, op. cit. supra note 10, at 10-11.

54 Comment, 11 CalfF. L. Rev. 276, 279 (1923); Comment, 34 Colum. L. Rev. 932, 939-40 (1934).

65 Ibid.

56 See Car. Code Crv. Proc. \$ 117 (h).

578 MIrute Book 14 (Special Issue, Jan. 1962).

58 Section $117(\mathrm{~g})$ of the Code of Civil Procedure, dealing with presentation of evidence, is silent on the point and there appear to be no California cases raising the issue. As a matter of practice, cross-examination is permitted or denied at the discretion of the small claims judge. Interview with J. R. McCloskey, Clerk of the Municipal Court, OaklandPiedmont-Emeryville Judicial District, Oct. 9, 1963.

59 See Slontz, op. cit. supra note 31, at 274-75.

${ }^{60}$ Simplified rules of practice and procedure have been called "the greatest single factor in the success of these courts." Instirute of JUdicial AdMINISTRATION, op. cit. supra note 10 , at 6 .

61 Some judges prefer submission in order to maintain dignity and decorun in the courtroom, particularly in rural areas where cases are more likely to become very heated. Address by Judge Swan of the Benicia (California) Justice Court to the Seminar in Court Administration, Boalt Hall, University of California, Novenuber 1963. Bitterness appears greatest when the htigants are personally acquainted, more likely to be true in rural areas.
} 
outcome by mail. ${ }^{62}$ The prevailing party is entitled to costs of suit. ${ }^{63}$

No attachment or garmishment may issue from the small claims court, ${ }^{64}$ but a writ of execution may be obtained upon the payment of a one dollar filing fee. ${ }^{65}$ Money or wages owing and unpaid to a small claims judgment debtor by the state or a county or municipality may be levied upon after judgment by filing an abstract of judgment with the appropriate agency or official. ${ }^{66}$ An abstract of judgment filed with the county recorder may be used to impress a lien on real property located in the county. ${ }^{67}$ As in other civil cases, the prevaihing claimant may initiate a supplementary proceeding or examination after judgment to discover the other party's assets. ${ }^{68}$

The Code of Civil Procedure does not contain a provision for new trials in small claims actions; apparently new trial motions are not entertained. ${ }^{69}$ While the plaintiff is bound by the decision of the small claims court, $^{70}$ the defendant may contest the decision by filing an appeal to the superior court within the prescribed period ${ }^{71}$ after the entry of judgment. An appeal requires the payment of various fees, ${ }^{\mathbf{7 2}}$ and either filing an undertaking on appeal ${ }^{73}$ or making a cash deposit. After

62 State of California Consumer Counch, How to Use the Samat Chams Court 7 (1962); 8 Minute Book 14 (Special Issue, Jan. 1962).

63 Cal. Code Crv. Proc. $\$ 117(\mathrm{~g})$. Costs include court costs, such as fees paid to subpoena witnesses, service costs, and cost of issuing the writ of execution. See STATE or CarrFORNIA CONSUMER Councm, op. cit. supra note 62, at 9. Costs incurred after judgment for any of the items allowed in CAL. CODE CIV. Proc. $\$ 1033.7$ can be collected by a special procedure involving a "Cost Bill After Judgment," described in 8 MINUTE Boox 37 (Special Issue, Aug. 1962).

64 Cad. Code Civ. Proc. \& 117(ha).

65 Cal. Code Civ. Proc. $\$ 117$ (p).

668 Mnute Book 31 (Special Issue, Aug. 1962). See Cal. Code Crv. Proc. $\$ 710$.

67 CaI. Code CIV. Proc. \$ 674.

68 Cax. Code Crv. Proc. \$ 714-15; 8 Minute Book 33 (Special Issue, Aug. 1962).

69 See 2 Minute Boox 123 (1956). In Spiegelman v. Boulus, 15 Cal. App. 2d Supp. 765,59 P.2d 225 (1936), the appellate department of the superior court held that where a statute provides a complete scheme of procedure for a particular action or proceeding, and expressly provides for appeal but not for a new trial, the latter remedy is unavailable. Wilson v. Dunbar, 36 Cal. App. 2d 144, 97 P.2d 262 (1939), is in accord with Spiegelman.

$70 \mathrm{Cal}$. Code CIv. Proc. \& $117(\mathrm{j})$. The predecessor of this section, giving defendant but denying plaintiff the right.to appeal, was held by the appellate department of the superior court to violate the 14th amendment by denying equal protection of the laws. Donohue $v$. Baker, 2 Rag. 19 (1929). Section $117(j)$ was held vahid, however, in City v. Alturas v. Superior Court, 36 Cal. App. 2d 457, 97 P.2d 816 (1940).

71 Effective July 1, 1964, the time for appeal is that prescribed in rules adopted by the Judicial Council. Prior to that date, defendant had 30 days from the entry of judgment to appeal. See Cad. Code CIv. Proc. \$ 117 (j) (old and new text).

72 The fees required are a filing fee of $\$ 10$, county law hbrary fee (varies), and a transmittal fee of $\$ 1.8$ MINUTe Book 25 (Special Issue, Aug. 1962).

73 This bond must be filed with two or more sureties and substantialiy in the form specified in Car. Code Crv. Proc. $\$ 117(1)$. 
service of notice of the appeal on plaintiff, ${ }^{74}$ a trial de novo is held in the superior court. ${ }^{75}$ The parties may be represented by attorneys. If the defendant is unsuccessful, he is required to pay to the plaintiff an attorney's fee of fifteen dollars in addition to the amount of the judgment. ${ }^{76}$

\section{II}

\section{RESULTS OF AN EMPIRICAL STUDY}

In order to gain msight into the operation of the Cahfornia small claims court, an empirical study of the court for the Oakland-PiedmontEmeryville judicial district was undertaken. A pilot study ${ }^{77}$ was first conducted to determine what information was available from court filing records. ${ }^{78}$ From an analysis of the results of the pilot study, a master key for procedure was developed for use with the main sample. ${ }^{79}$ Fiscal year $1963^{80}$ was chosen as the time period for the study because this was the most recent period for which complete records existed. Data were compiled for 386 cases. $^{81}$

74 Plaintiff must be served with notice of the appeal and the undertaking on appeal within 5 days of the filing of the appeal. Car. Code CIv. Proc. $\S 117(\mathrm{I})$.

75 Cal. Code Crv. Proc. \& 117(j).

70 The predecessor of $\S 117(j)$ was held unconstitutional in Donohue v. Baker, 2 Rag. 19 (1929), by the appellate department of the superior court, but was later held valid in Superior Wheeler Cake Corp. v. Superior Court, 203 Cal. 384, 264 Pac. 488 (1928).

77 The pilot study involved 50 claims.

78 The official records of the sinall elaims court consist of copies of plaintiffs' declarations on which information relevant to disposition of the action is entered. Entries include the names and addresses of plaintiff and defendant, a statement of the nature of the claim, the amount claimed, records and dates of service, date of trial, disposition of the case, costs, and proceedings after judgment.

79 A copy of the procedural key is on file with the California Law Review together with the complete project report. The full report contains 38 appendices and 45 detailed statistical tables. Also on file are the coded punch cards prepared for each case studied. See note 81 infra.

80 July 1, 1962 through June 30, 1963.

81 A random sample of 383 is said always to allow $95 \%$ confidence that the sample proportion will be within $5 \%$ of the true population proportion-that is, 95 times out of 100 , statistics within $5 \%$ of the actual percentages characteristic of the total population will be obtained. Dornbusch and Schmm, A Prtmer of Soctal Statistics 153-55 (1955). The technique of systematic sampling was employed: starting from a number selected at random, every $n$th claim is selected, $n$ being determined by the sample size desired. A systematic sample is presumably equivalent to a simple random sample where, as was true with the small claims studied, individual items are filed chronologically as received. Such a method of filing tends to eliminate periodic or cyclic characteristics which might otherwise produce distortion in the sample if the cycles corresponded to the sampling interval. See generally Bralock, Social Statistics 397-98 (1960).

Beginning with the 10th and 37 th claims filed in fiscal 1963, every 45 th case thereafter was included in the sample. The starting numbers were taken from a table of random numbers found in BLALOCE, at 437. Two numbers were selected to lessen the possibility of distortion. To conserve time and facilitate tabulation of the data, extracted information was coded and 


\section{A. Basic Data}

Users of the small claims court may conveniently be divided into four categories: individuals, proprietorships, ${ }^{82}$ corporations, and government agencies. Of all the actions filed, sliglitly more than thirty percent were brought by individuals. ${ }^{83}$ On the other hand, individuals were defendants in more than eighty-five percent of the cases. ${ }^{84}$ In other words, business and government interests initiated sixty percent of all actions and individuals defended more than eighty percent of them. Inasmuch as the small claims court was created primarily to help the "poor" litigant, ${ }^{85}$ it is questionable whether that purpose is actually being fulfilled in Alameda County; it appears that the poor litigant is far more likely to be defending than bringing an action in small claims court. An even more starthing statistic is that fully twenty percent of all claims were brought by government agencies, ${ }^{86}$ while less than one percent of the cases were brought against government agencies. ${ }^{87}$

The most frequent claim, nearly thirty percent, was for nonpayment for goods..$^{88}$ Fourteen percent of the claims involved charges for governmental services. ${ }^{89}$ More importantly, however, a number of claims ${ }^{00}$ involved delinquent personal property taxes. Tax matters are excluded from the jurisdiction of the municipal courts and hence from the jurisdiction of the small claims courts. ${ }^{91}$ Nevertheless, large numbers of tax cases

punched on cards. Royal McBee card No. K5S $671 \mathrm{~B}$ was chosen because it fulfilled the requirements of the sample. The perimeter of the card has 134 holes into which separate categories of information may be punched; 128 of the holes were actually used. In addition, the center of the card was used to write out information not susceptible to coding such as the names and addresses of plaintiff and defendant. With the aid of a rod device, the cards could then be sorted and data compiled rapidly. This system was especially useful in correlating different categories of information, such as type of claim with number of defaults. Correlates are described in note 120 infra.

82 Proprietorships were defined to include both individuals and partnerships doing business under a business name.

${ }^{83}$ See Appendix A, Table 1.

84 See Appendix A, Table 2.

85 Scott, Small Causes and Poor Litigants, 9 A.B.A.J. 457 (1923).

${ }^{86}$ See Appendix A, Table 1.

87 See Appendix A, Table 2.

88 See ibid.

${ }^{89}$ See ibid.

80 Eleven of the 386 items included in the sample were for delinquent personal property taxes. See ibid.

${ }^{91}$ Cac. Code Crv. Proc. $\$ \S 89$ and 112 provide that the jurisdiction of the municipal and justice courts does not extend to cases which involve the legality of any tax or assessment. The legality of a tax has been held to be involved where the taxpayer merely denies liability for the tax as well as where the validity of the tax statute itself is questioned. California Employment Stabilization Comm'n v. Citizens Nat'l Trust \& Sav. Bank, 73 Cal. App. 2d 915, 167 P.2d 752 (1946). Sinall claims courts, given jurisdiction over "cases for the recovery of money only" by CAx. Code Civ. Proc. $\S 117$, are also necessarily limited by the 
are filed by the County of Alameda in the small claims court. ${ }^{92}$ Court practice apparently varies: some judges do not allow tax cases to be tried; others hear them unless the defendant appears and objects, in which event the action is dismissed. ${ }^{93}$ Apparently, the county obtains default judgments in a substantial number of property tax cases. ${ }^{94}$

For purposes of the study, a category of claims entitled "group claims" was set up. A group claim was defined to be a claim filed simultaneously with a number of other claims by a particular plaintiff. More than half ${ }^{95}$ of all claims filed were group claims; the usual number of group claims filed together was between ten and fifteen. ${ }^{96}$

More than half ${ }^{97}$ of the claims were for amounts between twenty-five and one hundred dollars; ${ }^{98}$ few involved amounts under ten dollars. ${ }^{99}$ The large percentage of claims for exactly two hundred dollars ${ }^{100}$ indicates that many claims are reduced in amount to meet the jurisidictional limit of the small claims court. ${ }^{101}$

Nearly sixty-five percent ${ }^{102}$ of the cases reached the point where the judge took some action: tried the case, dismissed, or granted a continuance. ${ }^{103}$ In eighty percent of these cases ${ }^{104}$ the judge's action occurred within forty days after the claim was filed. It would be difficult to argue that the goal of speedy justice ${ }^{\mathbf{1 0 5}}$ is not being realized in the small claims court studied.

jurisdictional requirements for the municipal and justice courts of which they are an adjunct. It can be argued that the validity of the tax is not in question until the defendant appears and contests the inatter; therefore, the argument proceeds, in the absence of contest the matter can be heard, default entered and defendant bound. This seems to be the accepted theory under which small claims judges hear tax cases Apparently some judges, however, view tax matters as being beyond the small claims court's jurisdiction per se and refuse to try the case even where the defendant doesn't appear. See note 93 infra and accompanying text. Under this approach every tax case is assumed to involve the legality of the tax.

92 Presumably, approximately 280 per year, i.e., $2.9 \%$ of the 9653 sniall claims cases filed in fiscal year 1963.

83 Interview with Mr. J. R. McCloskey, Clerk of the Municipal Court, Oakland-Piedmont-Emeryville Judicial District, October 9, 1963.

84 The county obtained default judgment in 3 of the cases included in the sample. This indicates that perhaps 75 cases per year involving delinquent personal property tax claims are won by the county through default judgments.

$9559.3 \%$ of all claims filed.

96 See full report on file with California Law Review.

$8754.9 \%$ of all claims filed.

98 See Appendix A, Table 4.

$898.5 \%$ of all claims filed. See ibid.

$1009.1 \%$ of all claims filed. See ibid.

101 This conclusion seems particularly justified in light of the disparity between the percentage of claims for exactly $\$ 200$ and that for amounts between $\$ 175$ and $\$ 200: 9.1 \%$ versus $4.4 \%$. See ibid.

$10263.2 \%$ of all elaims filed.

$10356.5 \%$ were fully tried, $3.9 \%$ were dismissed at plaintiff's request at the time set for trial, and $2.8 \%$ were dropped when neither party appeared at the time of trial. 
Plaintiff received judgment in ninety percent of the cases that went to judgment. ${ }^{108}$ Since slightly over half of the cases initiated in small claims court go to judgment, ${ }^{107}$ judgment for plaintiff may be expected in about half of the claims filed, judgment for defendant in about six percent. ${ }^{108}$ It is noteworthy that termination without notification to the court occurred in more than twenty-five percent of the claims filed. ${ }^{100}$ Only forty percent of the cases that went to judgment were contested. ${ }^{110}$

Judgment for the plaintiff in small claims court generally means substantial success: in eighty-five percent of the cases in which plaintiff received judgment the amount awarded was at least seventy-five percent of the amount claimed. ${ }^{111}$ Costs were awarded the successful plaintiff in virtually every case; ${ }^{112}$ defendant was not allowed costs in any case. ${ }^{113}$ Costs allowed plaintiff amounted to less than six dollars in the overwhelming majority of cases. ${ }^{114}$ To this extent, it appears that the poor hitigant does benefit from the availability of the inexpensive small clains procedure, ${ }^{115}$ irrespective of the fact that he is more likely to be a defendant than a plaintiff. ${ }^{118}$

Statistics on post-judgment activity are sketchy because of the litigants' failure to provide information to the court. While the statute requires the creditor to record any satisfaction of the judgment, ${ }^{117}$ there appears to be no method of enforcing this provision absent affirmative action by the judgment debtor. One may suspect that not all judgments fully or partially satisfied are entered in the records. ${ }^{118}$ In any event, some type of recorded post-judgment activity occurred in more than half of the cases resulting im judgment for plaintiff. ${ }^{119}$

\footnotetext{
104 See Appendix A, Table 5.

105 See text accompanying notes 13-15 supra.

106 See Appendix A, Table 6.

$10756.5 \%$ of all claims filed. See ibid.

108 See ibid.

109 See ibid.

110 Both parties were present in 90 of the 218 cases fully tried.

111 See Appendix A, Table 7.

112 In 194 of the 195 judgments for plaintiff.

113 See Appendix A, Table 8.

114 Ibid.

115 See text accompanying notes 13-14 supra.

116 See text accoinpanying notes 83-84 supra.

117 Cat. Code Cry. Proc. \$ 675.

118 This suspicion finds support through the following reasoning: the county is exempt from the small claims filing fee under CAI. Gov'T CODE $\$ 6103$; however, the filing fee is included as part of the county's judgment, and upon collection of an anount equal to the filing fee under the judgment, the filing fee unust be remitted to the court. See CaL. Gov'T CODE $\S 6103.5$. Records in a number of cases showed that the filing fee had been received by the court, although no satisfaction of judgment appeared in the records.

119 See report on file with the California Law Review.
} 


\section{B. Correlates $^{120}$}

More than half of the claims brought by each type of plaintiff involved amounts between twenty-five and one hundred dollars. ${ }^{121}$ It appears that proprietorships, corporations, and government agencies never prosecute claims for less than ten dollars and individuals do so only rarely. ${ }^{122}$ Individuals and corporations appear to be the groups most likely to scale down claims to the two hundred dollar jurisdictional limit of the small claims court. ${ }^{123}$

By far the greatest number of corporate and proprietorship claims were for goods, services, or a combination of the two. ${ }^{124}$ Hospital services rendered accounted for nearly seventy-five percent of the claims brought by government agencies. ${ }^{125}$ More than half of the claims brought by individuals were for either property damage or rent. ${ }^{128}$

Sixteen organizations accounted for nearly forty-five percent of all claims filed during the period studied. ${ }^{127}$ The largest and the most successful user of the court is the County of Alameda. ${ }^{128}$ The county brought nearly twenty percent of all the claims filed; ${ }^{129}$ further, nearly all of the county's claims were group claims, one of which comprised ninetyseven individual claims. ${ }^{130}$ In no case did defendant prevail against the county after trial.

Approximately twenty percent of all claims were brought against out-of-county defendants. ${ }^{131}$ Nearly fifty percent of the actions brought by corporations, however, were against out-of-county defendants. ${ }^{132}$ Inasinuch as fewer out-of-county defendants appear at trial than in-county defendants, ${ }^{133}$ it might be surmised that the default rate would be higher

120 After tabulation of the basic data by subject (e.g., type of claim, type of plaintiff), it was possible through utilization of the Royal McBee punch cards (see note 81 supra) to correlate between any two informational categories. Thus, for example, the number of corporate plaintiffs bringing claims for amounts between $\$ 100$ and $\$ 125$ could be determined. A list of likely correlates was prepared and data compiled. Some of the correlates were completely insignificant and are not discussed in this comment.

121 See Appendix B, Table 1.

122 See ibid.

123 See ibid.

124 See Appendix B, Table 2.

120 See ibid.

126 See $i b i d$.

127 See Appendix B, Table 3.

128 See $i b i d$.

120 See $i b i d$.

180 See $i b i d$.

131 See Appendix B, Table 4.

182 See ibid.

133 See ibid. 
for corporations. Results of the study support this notion: eighty-three percent of all actions brought by corporations which went to judgment ended in default, ${ }^{134}$ whereas the default for all actions going to judgment was only sixty percent. Further, nearly half of all corporate claims ended in default; this compares with the overall rate of slightly more than thirty percent. ${ }^{135}$ In summary, it seems clear that a small claims action brought by a corporation is much more likely to be against an out-ofcounty defendant than an action brought by any other type of plaintiff; and it is much more bikely that an action brought by a corporation will result in default judgment.

Individuals defended more than eighty percent of the cases studied. ${ }^{180}$ Consequently, correlates between type of defendant and other categories are less significant than most of the correlates developed. In any event, it appears that the relative success of corporate defendants, both in winning cases ${ }^{137}$ and in minimizing judgments in the cases lost, ${ }^{138}$ merely reflects the greater degree of business sophistication and legal prowess of corporations vis-à-vis individuals and proprietorships.

Seventy-five percent of all property damage claims were contested; in most of the other types of claims the defendant was more likely to be absent than present. ${ }^{139}$ Property damage cases involved witnesses about thirty percent of the time and accounted for more than half of the tried cases in which witnesses were present for at least one of the parties. ${ }^{140}$ Defendants were most successful in property damage cases, winning more than twenty-five percent of those going to judgment; ${ }^{141}$ in all other types of cases defendant fared quite badly. ${ }^{142}$

Of the cases going to judgment, government agencies were most likely to be awarded the full amount claimed; ${ }^{143}$ individuals were least likely to be wholly successful. ${ }^{144}$ Corporate plaintiffs were less than wholly successful in more than thirty percent of the cases they won. This is particularly significant in light of the fact that forty-eight of the fifty-

134 See Appendix B, Table 5.

135 See ibid.

136 See Appendix A, Table 2.

137 See Appendix B, Table 6.

138 See Appendix B, Table 7.

139 The table setting forth these correlates is not presented here due to space limitations. Interested readers may see the full project report on file at the office of the Califormia Law Revierw.

140 See note 139 supra.

141 See note 139 supro.

142 See note 139 supra.

143 See Appendix B, Table 8.

144 See ibid. 
three successful corporate claims were default cases. Clearly, default does not automatically mean complete victory for the corporate plaintiff.

\section{III}

\section{CONCLUSIONS AND SUGGESTIONS FOR REFORM}

Results of the study, considered in the context of current procedural requirements, suggest five possible areas of reform. About twenty percent of all claims were brought against out-of-county defendants, many of whom were from distant counties. This is a possible source of injustice, since the statutory procedure for small claims makes no provision for discretionary change of venue in Cahfornia. ${ }^{145} \mathrm{It}$ would be possible at the present time for a Los Angeles business firm to send salesmen to the Sacramento area to peddle shoddy or over-priced merchandise. Since orders constitute offers which are accepted in Los Angeles, the contract has technically been entered into in Los Angeles. ${ }^{146}$ Therefore, if the defendant in Sacramento stopped his time payments because of the poor quahty of the merchandise, the company would be free to bring the action in Los Angeles. The small claims court apparently would be powerless to permit a change of venue..$^{147}$

Because of the relative ease with which the plaintiff could sue in Sacramento, as compared with the burden upon defendant to defend in Los Angeles, considerations of equity would seem to require that discretionary change of venue be permitted. It is therefore suggested that a limited change of venue provision be added to the small claims code provisions. Under sucl a provision, the judge could transfer the case to the county of defendant's residence whenever the facts warrant transfer. The motion could be made by mail. An alternative solution would be to amend the statute to allow actions to be brought only in the county of defendant's residence. However, since there may be cases where it would be equally inequitable to require a plaintiff to travel to a distant county to prosecute a claim, ${ }^{148}$ the discretionary change of venue provision seems preferable.

Of all the claims filed, almost three percent were for delinquent personal property taxes-claims seemingly beyond the jurisdiction of the small claims court. ${ }^{149}$ Three of these claims went to trial and resulted in

145 See note 35 supra and text accompanying notes 131-33 supra.

146 See note 34 supra and accompanying text.

147 But see text accompanying note 36 supra.

148 For example, where a defendant from a distant county purchases merchandise with a bad check, it might be inequitable to force plaintiff to bring the action only where defendant resides.

149 See note 91 supra and accompanying text. 
judgment for plaintiff. One means of preventing such extra-jurisdictional judgments miglit be an explicit statutory prohibition on the hearing of tax cases; alternatively, the statute might be amended to authorize trial of tax cases involving amounts within the small claims court's jurisdictional limits.

In the interests of accurate judicial record keeping, a method should be adopted to ensure notification to the court in all cases resulting in partial or complete satisfaction of judgment. The incompleteness of judgment records apparently results from the lack of an effective means to compel the plaintiff to notify the court that the judgment has been wholly or partially satisfied. Althougl such notification is presently required by statute, the notification depends almost entirely on some affirmative action by the defendant if the plaintiff fails to notify the court. Perhaps a small fine for failure to notify would provide the necessary stimulus to plaintiffs. Alternatively, it could be required that all payments of money be channelled through the office of the court clerk.

While the courts of some other states lave a limit higher than two hundred dollars, no cogent reason appears why the jurisdictional limit should be raised at this time. Most of the claims involved amounts between twenty-five and one hundred dollars. ${ }^{150}$ There is a sliglit bunching of claims for exactly two liundred dollars, ${ }^{151}$ but this is not sufficient to warrant an increase of jurisdictional amount. Periodic increases in the jurisdictional limit to adjust for inflation seem justified; raismg the limit for other reasons, however, appears unjustified in light of California's provision absolutely barring attorneys from small claims proceedings. ${ }^{162}$

The statutory provision barring actions by assignees ${ }^{163}$ was aimed at preventing professional collection agencies from using the small claims court. The study revealed that about forty-five percent of the total volume of cases handled by the court are attributable to sixteen group claimants. ${ }^{154}$ While none of these plaintiffs are specifically engaged in the collection business, use of the small claims court procedure by large business group claimants amounts to professional collection. ${ }^{155}$. The orig-

150 See Appendix A, Table 4.

151 See ibid.

152 CAX. Code Crv. Proc. § $117(\mathrm{~g})$; see text accompanying note 24 supra. For criticism of the absolute bar of attorneys, see Report of the Committee on Small Claims and Conciliation Procedures of the Conference of Bar Association Delegates, 10 A.B.A.J. 828 (1924);

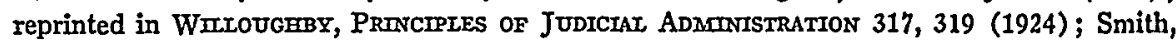
Small Claims Procedure is Succeeding, 8 J. Axr. JoD. Soc's 247, 252 (1924); Comment, 34 ConUs. L. Rev. 932, 937-38 (1934). These authorities point out that absolute prohibition of attorneys may deprive a frightened or illiterate litigant of a needed spokesman.

153 See note 22 supra and accompanying text.

154 See Appendix B, Table 3.

155 The practice has been increasing throughout the United States. See INSTITUTE or 
inal aim of the small claims court to provide an inexpensive, informal procedure for the plaintiff of limited means has no application to the large busmess group claimant. ${ }^{156}$ On the other hand, there may be valid contemporary reasons for permitting the use of the small claims court by business claimants. For example, it seems clear that the availability of small claims procedure tends to relieve formal courts of the handling of petty claims. Also, there seems to be no self-evident reason why business plaintiffs should not be permitted to obtain justice in small disputes at a mininum expenditure of cost and time. The results of the study indicate the necessity for reexamining the purposes of the small claims court in a modern context.

Finally, additional studies of particular small claims courts are desirable. Conparison of a nunber of such studies would provide a broad insight into the workings of the court and would protect against the possibility that atypical local conditions vitiate generahzations based on the characteristics of a single court. For example, in rural counties corporate and group clains niay be small in number or nonexistent; consequently, results obtained from study of a rural court might be significantly different from those derived from the Oakland study. ${ }^{157}$ Further

Judicial Adamistration, Smfale Ceatuss Courts in the United States 1-2 (1959 Supp.): "Collection agents and professional men employ the small claims court's facilities in increasing number. However, no serious objection has been raised to this tendency; in fact, two states... have deleted from their statutes a limitation on the, number of claims which an individual may bring before the court during a particular week or month. This action would seem to encourage the use of small claims courts by repeating claimants as well as by the occasional litigant."

156 "Since the court was established primarily for the litigant with modest means who is inexperienced in legal matters, it would seem that extensive use of the procedure by business firms is outside the court's original purpose. These businesses have employees who handle collection matters regularly and who become expert in using this simple device. They are not poor litigants who would have to give up the claim rather than resort to some other method of collection. They choose the small claims court mainly because it is the easiest method for them to collect their claims. Therefore, permitting them to use the courts in this way is a departure froin the primary purpose for which the courts were established. If they are to be allowed to continue to use the small claims courts for collections, it must be recognized that this use is permitted for other reasons .... There are ... good reasons for restricting this collection practice. Small claims courts are run with a loss to the taxpayer. They are an extra service. Depriving a company of this mechanism is not removing from its hands the instrument of justice. Rather, it is requiring them to use the more cumbersome, but still appropriate formal courts. After all, in the small claims courts these firms are handling their claims in a formal and systematic manner quite in keeping with lawyer-staffed courts. In small claims courts they bring their experience to bear on defendants who do not have lawyers and who are unfamiliar with legal procedure. And of course there is the danger that companies will extend credit to individuals more readily, knowing that they can resort to the small claims court for collection." Comment, 4 STAN. L. REv. 237, 241-42 (1952).

167 Tentative results from an unpublished study of the Berkeley-Albany small claims court for 1963 indicate that very few corporate plaintiffs and almost no group claims are to be found in that court. 
studies would provide the foundation for an accurate analysis of the current functioning of the small claims court.

Carl R. Pagter*

Robert McCloskey**

Mitchell Reinis***

*LL.B., 1964, University of California, Berkeley.

** LL.B., 1964, University of California, Berkeley.

*** LL.B., 1964, University of California, Berkeley. 


\section{APPENDIX A: BASIC DATA}

TABLE 1

Type of Plaintiff

\begin{tabular}{lcc}
\hline \multicolumn{1}{c}{ Type } & Number of Clains & Percentage \\
\hline Individual & 134 & 34.7 \\
Proprietorship & 65 & 16.8 \\
Corporation & 110 & 28.5 \\
Government Agency & 77 & 20.0 \\
$\quad$ Total & 386 & 100.0 \\
\hline
\end{tabular}

TABLE 2

Type of Defendant

\begin{tabular}{lcc}
\hline \multicolumn{1}{c}{ Type } & Number of Claims & Percentage \\
\hline Individual & 331 & 85.7 \\
Proprietorship & 34 & 8.8 \\
Corporation & 13 & 3.4 \\
Government Agency & 1 & .3 \\
Other & 7 & 1.8 \\
$\quad$ Total & 386 & 100.0 \\
\hline
\end{tabular}

TABLE 3

Type of Claim

\begin{tabular}{lcc}
\hline \multicolumn{1}{c}{ Type } & Number of Claims & Percentage \\
\hline Goods & 114 & 29.5 \\
Governmental Services & 55 & 14.2 \\
Property Damage & 49 & 12.7 \\
Non-governmental Services & 36 & 9.3 \\
Rent & 30 & 7.8 \\
Goods and Services & 24 & 6.2 \\
Loans & 16 & 4.1 \\
Refunds & 13 & 3.4 \\
Personal Property Taxes & 11 & 2.9 \\
Breach of Contract-other & 10 & 2.6 \\
Damages for non-performance & & 2.3 \\
or faulty performance of services & 9 & 5.0 \\
All Other & 19 & 100.0 \\
\multicolumn{1}{r}{ Total } & 386 &
\end{tabular}


Table 4

Amount of Claim

\begin{tabular}{|c|c|c|c|}
\hline \multirow[b]{2}{*}{ Over } & Amount & \multirow[b]{2}{*}{ Number of Claims } & \multirow[b]{2}{*}{ Percentage } \\
\hline & Including & & \\
\hline$\$ 0$ & $\$ 10$ & $\cdot$ & .5 \\
\hline 11 & 25 & 31 & 8.0 \\
\hline 26 & 50 & 80 & 20.7 \\
\hline 51 & 75 & 67 & 17.4 \\
\hline 76 & 100 & 65 & 16.8 \\
\hline 101 & 125 & 24 & 6.2 \\
\hline 126 & 150 & 39 & 10.1 \\
\hline 151 & 175 & 26 & 6.7 \\
\hline 176 & 199 & 17 & 4.4 \\
\hline 199 & 200 & 35 & 9.1 \\
\hline \multicolumn{2}{|c|}{ Total } & 386 & 100.0 \\
\hline
\end{tabular}

TABLE 5

Time from Filing Date to Trial Date

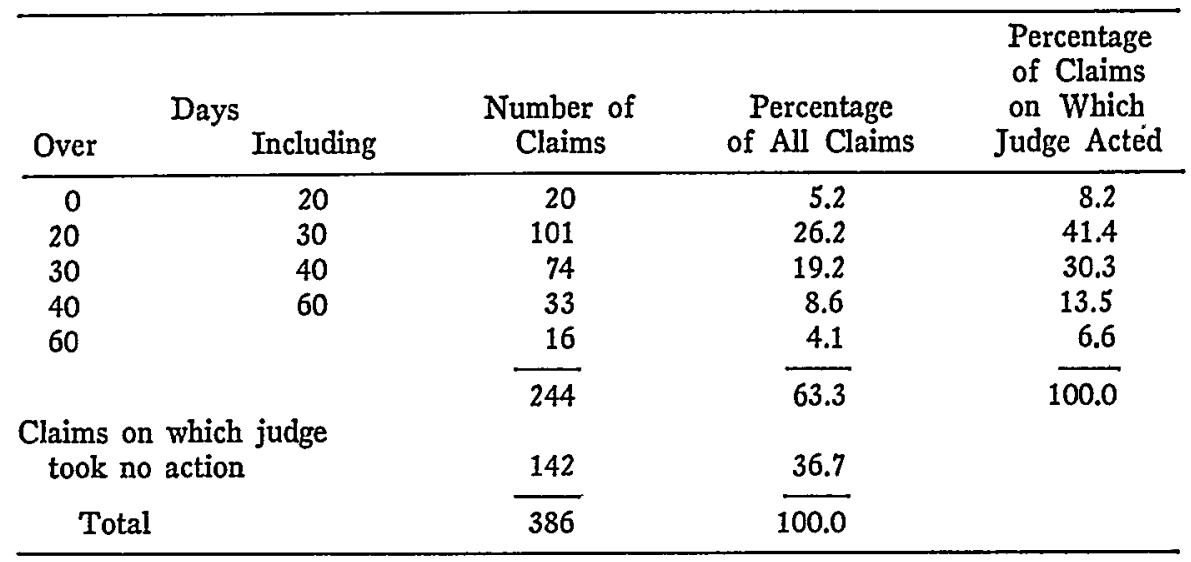

TABLE 6

Disposition of Case

\begin{tabular}{lccc}
\hline \multicolumn{1}{c}{ Disposition } & $\begin{array}{c}\text { Number of } \\
\text { Claims }\end{array}$ & $\begin{array}{c}\text { Percentage } \\
\text { of All Claims }\end{array}$ & $\begin{array}{c}\text { Percentage of Claims } \\
\text { Going to Judgment }\end{array}$ \\
\hline Judgment for Plamtiff & 195 & 50.5 & 89.5 \\
Judgment for Defendant & $\frac{23}{218}$ & $\frac{6.0}{56.5}$ & $\underline{10.5}$ \\
& 66 & 17.1 & \\
$\begin{array}{l}\text { Dismissed at Plaintiff's } \\
\text { Request }\end{array}$ & $\underline{26.4}$ & \\
Not Tried for Other Reasons & 102 & $\underline{100.0}$ & 100.0 \\
$\quad$ Total & 386 & &
\end{tabular}


TABLE 7

Amount of Judgment (for Plaintiff)

\begin{tabular}{|c|c|c|c|c|}
\hline \multicolumn{2}{|c|}{$\begin{array}{l}\text { Amount of Judgment } \\
\text { as a Percentage } \\
\text { of Claim }\end{array}$} & $\begin{array}{l}\text { Number of } \\
\text { Claims }\end{array}$ & $\begin{array}{l}\text { Percentage } \\
\text { of All Claims }\end{array}$ & $\begin{array}{l}\text { Percentage of Claims } \\
\text { Going to Judgment } \\
\text { for Plaintiff }\end{array}$ \\
\hline & 100 & 132 & 34.2 & 67.7 \\
\hline 75 & 99 & 35 & 9.0 & 17.9 \\
\hline 50 & 75 & 13 & 3.4 & 6.7 \\
\hline 25 & 50 & 7 & 1.8 & 3.6 \\
\hline \multirow[t]{2}{*}{0} & 25 & 8 & 2.1 & 4.1 \\
\hline & & 195 & 50.5 & \\
\hline \multicolumn{5}{|c|}{ Claims Not Resulting in } \\
\hline \multicolumn{2}{|c|}{ Judgment for Plaintiff } & 191 & 49.5 & \\
\hline \multicolumn{2}{|c|}{ Total } & 386 & 100.0 & 100.0 \\
\hline
\end{tabular}

TABLE 8

Cost Allowed Plaintiff

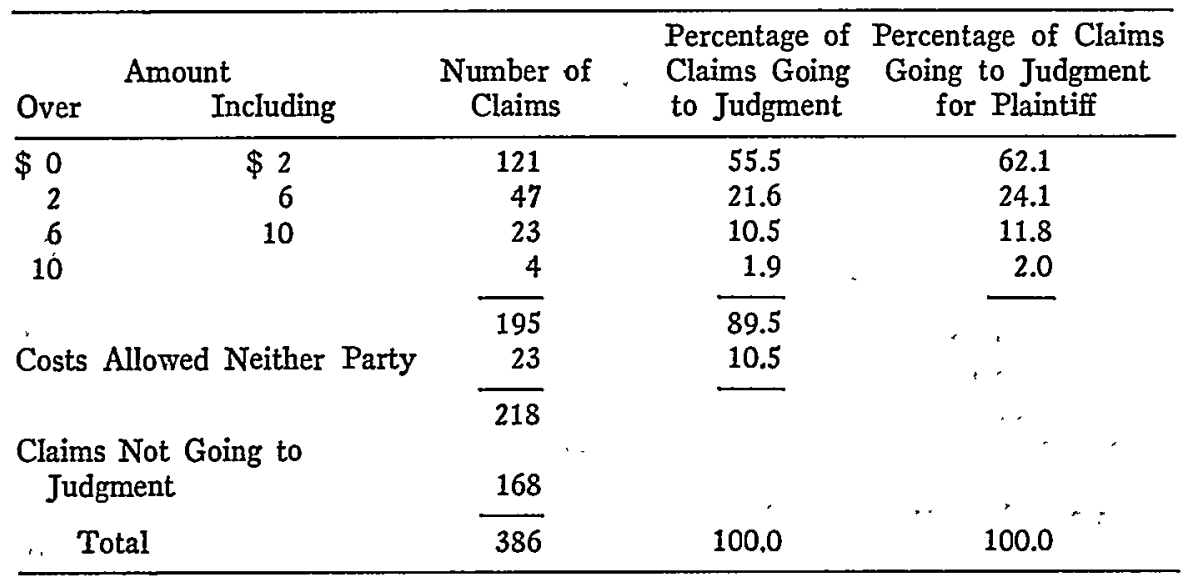




\section{APPENDIX B: CORRELATES}

TABLE 1

Amount of Claim by Type of Plaintiff

\begin{tabular}{|c|c|c|c|c|c|c|}
\hline \multirow[b]{2}{*}{ Over } & & \multicolumn{5}{|c|}{ Number of Claims Brought by: } \\
\hline & Including & Individual & Proprietorship & Corporation & Government & All \\
\hline$\$ 0$ & $\$ 10$ & 2 & 0 & 0 & 0 & 2 \\
\hline 10 & 25 & 8 & 10 & 8 & 5 & 31 \\
\hline 25 & 50 & 22 & 12 & 27 & 19 & 80 \\
\hline 50 & 75 & 27 & 14 & 11 & 15 & 67 \\
\hline 75 & 100 & 27 & 9 & 20 & 9 & 65 \\
\hline 100 & 125 & 7 & 4 & 9 & 4 & 24 \\
\hline 125 & 150 & 11 & 1 & 13 & 14 & 39 \\
\hline 150 & 175 & 4 & 6 & 7 & 9 & 26 \\
\hline 175 & 199 & 8 & 4 & 3 & 2 & 17 \\
\hline 199 & 200 & 18 & 5 & 12 & 0 & 35 \\
\hline & & 134 & 65 & 110 & 77 & 386 \\
\hline
\end{tabular}

TABLE 2

Type of Claim by Type of Plaintiff

\begin{tabular}{|c|c|c|c|c|c|}
\hline Type of Claim & Individual & $\begin{array}{r}\text { Number of } \\
\text { Proprietorship }\end{array}$ & $\begin{array}{c}\text { Claims Brough } \\
\text { Corporation }\end{array}$ & $\begin{array}{l}\text { at by: } \\
\text { Government }\end{array}$ & All \\
\hline Goods & 8 & 31 & 75 & 0 & 114 \\
\hline Governmental Services & 0 & 0 & 0 & 55 & 55 \\
\hline $\begin{array}{l}\text { Property Damage } \\
\text { Non-Governmental }\end{array}$ & 45 & 0 & 2 & 2 & 49 \\
\hline Services & 9 & 17 & 10 & 0 & 36 \\
\hline Rent & 25 & 0 & 0 & 5 & 30 \\
\hline Goods and Services & 5 & 13 & 6 & 0 & 24 \\
\hline Loans & 6 & 0 & 10 & 0 & 16 \\
\hline Refunds & 9 & 0 & 0 & 4 & 13 \\
\hline $\begin{array}{l}\text { Personal Property Taxes } \\
\text { Breach of Contract- }\end{array}$ & 0 & 0 & 0 & 11 & 11 \\
\hline Other & 4 & 1 & 5 & 0 & 10 \\
\hline $\begin{array}{l}\text { Damages for non-per- } \\
\text { formance or faulty }\end{array}$ & s & 1 & 0 & 0 & \\
\hline All Other & 15 & 2 & 2 & 0 & 19 \\
\hline Total & 134 & 65 & 110 & 77 & 386 \\
\hline
\end{tabular}


TABLE 3

Heavy Users of the Small Claims Court

\begin{tabular}{|c|c|c|c|}
\hline Plaintiff & $\begin{array}{l}\text { Number of } \\
\text { Claims }\end{array}$ & $\begin{array}{l}\text { Percentage of } \\
\text { All Claims }\end{array}$ & $\begin{array}{l}\text { Largest Number } \\
\text { of Group Claims } \\
\text { Submitted } \\
\text { Together }\end{array}$ \\
\hline County of Alameda & 70 & 18.1 & 97 \\
\hline Rhodes Department Store & 16 & 4.1 & 34 \\
\hline Montgomery Ward & 14 & 3.6 & 14 \\
\hline Milens Jewelers & 14 & 3.6 & 18 \\
\hline General Refrigeration & 8 & 2.1 & 5 \\
\hline Goldman's & 6 & 1.6 & 14 \\
\hline Creamcrest Dairy & 6 & 1.6 & 29 \\
\hline Mark-it List Publications & 6 & 1.6 & 10 \\
\hline King's Jewelers & 5 & 1.3 & 16 \\
\hline State of Cahifornia & 5 & 1.3 & 4 \\
\hline Seaboard Finance Co. & 5 & 1.3 & 11 \\
\hline Meni-Ketti Music Co. & 3 & .8 & 5 \\
\hline Dreyco Sales & 3 & .8 & 6 \\
\hline Sears Roebuck \& Co. & 3 & .8 & 3 \\
\hline C. Markus Hardware & 3 & .8 & 11 \\
\hline W. T. Grant Co. & 3 & .8 & 14 \\
\hline Total & 170 & 44.2 & \\
\hline
\end{tabular}

TABLE 4

Type of Plaintiff by Defendant's Residence

\begin{tabular}{lccr}
\hline Type of Plaintiff & Number of Claims Brought against & $\begin{array}{c}\text { Defendant } \\
\text { Residing: } \\
\text { Out-of-County }\end{array}$ & All \\
\hline Individual & In-County & 15 & 134 \\
Proprietorship & 119 & 8 & 65 \\
Corporation & 57 & 50 & 110 \\
Governmental Agency & 60 & 4 & 77 \\
$\quad$ Total & 73 & .77 & 386 \\
\hline
\end{tabular}

TABLE 5

\begin{tabular}{lcccc}
\hline Type of Plaintiff & $\begin{array}{c}\text { Number of } \\
\text { Claims }\end{array}$ & $\begin{array}{c}\text { Number of } \\
\text { Claims Going } \\
\text { to Judgment }\end{array}$ & $\begin{array}{c}\text { Number of } \\
\text { Defaults }\end{array}$ & $\begin{array}{c}\text { Defaults } \\
\text { Percentage } \\
\text { of All Claims }\end{array}$ \\
\hline Individual & 134 & 85 & 28 & 20.9 \\
Proprietorship & 65 & 37 & 26 & 40.0 \\
Corporation & 110 & 58 & 48 & 43.6 \\
Government Agency & $\mathbf{7 7}$ & $\mathbf{3 8}$ & $\mathbf{2 7}$ & 35.0 \\
$\quad$ & $\mathbf{3 8 6}$ & $\mathbf{2 1 8}$ & $\mathbf{1 2 9}$ & \\
\hline
\end{tabular}


TABLE 6

Type of Defendant by Disposition

\begin{tabular}{lccr}
\hline Type of Defendant & $\begin{array}{c}\text { Judgment } \\
\text { for Plaintiff }\end{array}$ & $\begin{array}{c}\text { Judgment } \\
\text { for Defendant }\end{array}$ & All \\
\hline Individual & 172 & 16 & 188 \\
Proprietorship & 15 & 2 & 17 \\
Corporation & 4 & 3 & 7 \\
Government Agency & 0 & 1 & 1 \\
Other & 4 & 1 & 5 \\
$\quad$ Total & 195 & 23 & 218 \\
\hline
\end{tabular}

TABLE 7

Type of Defendant by Amount of Judgment

\begin{tabular}{|c|c|c|c|c|c|}
\hline Type of Defendant & $\begin{array}{l}\text { Judgment } \\
\text { Equal to } \\
\text { Claim }\end{array}$ & $\begin{array}{l}76-100 \% \\
\text { of Claim }\end{array}$ & $\begin{array}{l}51-75 \% \\
\text { of Claim }\end{array}$ & $\begin{array}{l}26-50 \% \\
\text { of Claim }\end{array}$ & $\begin{array}{l}25 \% \text { or } \\
\text { Less than } \\
\text { P's Claim }\end{array}$ \\
\hline Individual & 177 & 31 & 12 & 6 & 6 \\
\hline Proprietorship & 12 & 1 & 1 & 1 & 0 \\
\hline Corporation & 1 & 3 & 0 & 0 & 0 \\
\hline Government Agency & 0 & 0 & 0 & 0 & 0 \\
\hline Other & 2 & 0 & 0 & 0 & 2 \\
\hline Total & 192 & 35 & 13 & 7 & 8 \\
\hline
\end{tabular}

TABLE 8

Type of Plaintiff by Amount of Judgment

\begin{tabular}{|c|c|c|c|c|c|}
\hline Type of Plaintiff & $\begin{array}{l}\text { Judgment } \\
\text { Equal to } \\
\text { Claim }\end{array}$ & $\begin{array}{l}76-99 \% \\
\text { of Claim }\end{array}$ & $\begin{array}{l}51-75 \% \\
\text { of Claim }\end{array}$ & $\begin{array}{l}26-50 \% \\
\text { of Claim }\end{array}$ & $\begin{array}{l}25 \% \text { or } \\
\text { Less than } \\
\text { Claim }\end{array}$ \\
\hline Individual & 39 & 12 & 10 & 4 & 4 \\
\hline Proprietorship & 26 & 7 & 1 & 1 & 0 \\
\hline Corporation & 33 & 14 & 1 & 1 & 4 \\
\hline Government Agency & 34 & 2 & 1 & 1 & 0 \\
\hline Total & 132 & 35 & 13 & 7 & 8 \\
\hline
\end{tabular}

